\title{
Leukemia Inhibitory Factor Is a Key Signal for Injury-Induced Neurogenesis in the Adult Mouse Olfactory Epithelium
}

\author{
S. Bauer, ${ }^{1}$ S. Rasika, ${ }^{2}$ Jing Han, ${ }^{2}$ C. Mauduit, ${ }^{3}$ M. Raccurt, ${ }^{4}$ G. Morel, ${ }^{4}$ F. Jourdan, ${ }^{1}$ M. Benahmed, ${ }^{3}$ E. Moyse, ${ }^{1}$ and \\ P. H. Patterson ${ }^{2}$ \\ ${ }^{1}$ Unité Mixte de Recherche 5020 Centre National de la Recherche Scientifique, Université Lyon I, 69622 Villeurbanne, France, ${ }^{2 B i o l o g y}$ Division, California \\ Institute of Technology, Pasadena, California 91125, ${ }^{3} \mathrm{U} 407$ Institut National de la Santé et de la Recherche Médicale, Hôpital Lyon-Sud, 69921 Pierre- \\ Bénite, France, and ${ }^{4}$ Unité Mixte de Recherche 5123 Centre National de la Recherche Scientifique, Université Lyon I, 69622 Villeurbanne, France
}

The mammalian olfactory epithelium $(\mathrm{OE})$ is composed of primary olfactory sensory neurons (OSNs) that are renewed throughout adulthood by local, restricted neuronal progenitor cells. The molecular signals that control this neurogenesis in vivo are unknown. Using olfactory bulb ablation (OBX) in adult mice to trigger synchronous mitotic stimulation of neuronal progenitors in the $0 \mathrm{E}$, we show the in vivo involvement of a cytokine in the cellular events leading to the regeneration of the $\mathrm{OE}$. We find that, of many potential mitogenic signals, only leukemia inhibitory factor (LIF) is induced before the onset of neuronal progenitor proliferation. The rise in LIF mRNA expression peaks at $8 \mathrm{hr}$ after OBX, and in situ RT-PCR and immunocytochemistry indicate that LIF is upregulated, in part, in the injured neurons themselves. This rise in LIF is necessary for injury-induced neurogenesis, as OBX in the LIF knock-out mouse fails to stimulate cell proliferation in the $\mathrm{OE}$. Moreover, delivery of exogenous LIF to the intact adult OE using an adenoviral vector stimulates BrdU labeling in the apical OE. Taken together, these results suggest that injured OSNs release LIF as a stimulus to initiate their own replacement.

Key words: LIF; gp130; IL-6; BMP; stem cells; olfaction

\section{Introduction}

The mammalian olfactory epithelium $(\mathrm{OE})$ is a pseudostratified epithelium made up predominantly of odorant-receptive neurons that project to the olfactory bulb (OB). These olfactory sensory neurons (OSNs) are renewed throughout adulthood by the mitotic activity of local neuronal progenitors, the globose basal cells (GBCs) (Monti-Graziadei and Graziadei, 1979; Caggiano et al., 1994; for review, see Schwob, 2002). The GBCs display neuronal phenotypic markers and were shown by lineage analysis to exclusively generate OSNs and GBCs in the normal, noninjured adult OE (Caggiano et al., 1994; Hunter et al., 1994).

Olfactory neuron renewal is strongly stimulated by ablating the OB [olfactory bulbectomy (OBX)], which leads to a wave of neuronal apoptosis in the $\mathrm{OE}$, peaking at 36-48 $\mathrm{hr}$ after lesion (Michel et al., 1994; Holcomb et al., 1995; Deckner et al., 1997), and to a subsequent wave of GBC mitosis peaking at $5 \mathrm{~d}$ after lesion in the C57BL/6 adult mouse (Schwartz-Levey et al., 1991). In this paradigm, mitotic stimulation consists of an increased number of neuronal progenitors entering the cell cycle (Schwartz-Levey et al., 1991; Huard and Schwob, 1995), which leads to the appearance of new neurons in the apical layer of the OE (Caggiano et al., 1994; Hunter et al., 1994). The delay separating apoptosis of mature neurons and the onset of progenitor

Received Sept. 1, 2002; revised Dec. 4, 2002; accepted Dec. 13, 2002.

This study was supported by Association pour la Recherche sur le Cancer Grant 1377 (E.M.) and by Fondation de Gérontologie Française and Société de Biologie du Vieillissement (S.B.), as well as by the National Institute of Neurological Disorders and Stroke (P.H.P.). We thank Doreen McDowell and Catherine Berthet for excellent administrative assistance. We thank Dr. Emmanuelle Danty for the OMP cDNA plasmid.

Correspondence should be addressed to P. H. Patterson, at the above address. E-mail: php@caltech.edu. Copyright $\odot 2003$ Society for Neuroscience $\quad 0270-6474 / 03 / 231792-12 \$ 15.00 / 0$ proliferation suggests that basal cells are stimulated to divide by local signals emitted during lesion-induced neuronal apoptosis.

Candidate signals for this stimulation are growth factors and cytokines (for review, see Mackay-Sim and Chuah, 2000) that have been shown to stimulate the production of new olfactory neurons in vitro, including leukemia inhibitory factor (LIF) (Satoh and Yoshida, 1997a,b), epidermal growth factor (EGF) (Mahanthappa and Schwarting, 1993; Farbman and Buchholz, 1996), TGF- $\alpha$ (Farbman and Buchholz, 1996), TGF $\beta 1$ and TGF $\beta 2$ (Mahanthappa and Schwarting, 1993; Newman et al., 2000), FGF 2 (DeHamer et al., 1994; MacDonald et al., 1996; Goldstein et al., 1997; Satoh and Yoshida, 1997a; Ensoli et al., 1998; Newman et al., 2000), FGFs 1, 4, 7 (DeHamer et al., 1994), and the neurotrophin family, NT-3, NT-4/5, and BDNF (Holcomb et al., 1995; Roskams et al., 1996). Some of these growth factors and their receptors have also been localized in the intact OE of adult rodents in vivo (Deckner et al., 1993; Farbman and Buchholz, 1996; Krishna et al., 1996; Roskams et al., 1996; SalehiAshtiani and Farbman, 1996; Goldstein et al., 1997; Buckland and Cunningham, 1999; Ohta and Ichimura, 1999; Hsu et al., 2001), and systemic injection of EGF or TGF $\alpha$ stimulates receptordependent phosphorylation in basal cells of the OE (Ezeh and Farbman, 1998). Moreover, local application of NGF in the nasal cavity of adult rodent can enhance OSN survival after olfactory nerve section (Yasuno et al., 2000), whereas subcutaneous injections of EGF, TGF $\alpha$, or FGF 2 enhance the regeneration of OSN after chemical lesion to the OE (Herzog and Otto, 1999).

It remains to be determined, however, whether these or other paracrine signals are required for the various steps of olfactory neuron turnover in vivo. To investigate this question we used the 
paradigm of OBX in the adult mouse. Because this operation leads to widespread death and birth of primary olfactory neurons (Schwartz-Levey et al., 1991; Michel et al., 1994; Holcomb et al., 1995), the prediction is that the surge in neurogenesis will be preceded by an upregulation of the appropriate endogenous mitogen(s) (for review, see Mackay-Sim and Chuah, 2000; Schwob, 2002).

\section{Materials and Methods}

Animals and surgery. For analysis of cytokine expression, three-monthold mice of the C57BL/6 strain (Iffa Credo, l'Arbresle, France) were subjected to bilateral OBX as described previously (Michel et al., 1994). Under anesthesia with equithesine $(0.3 \mathrm{ml} / 100$ gm body weight, i.p. $)$, the scalp was incised, and two symmetrical, 1-mm-wide holes were drilled in the skull above the olfactory bulbs, which were then removed by aspiration through a curved glass pipette connected to a vacuum pump. After the cavities were filled with sterile Gelfoam and the skin was sutured, mice were allowed to recover and returned to standard cage conditions. Animals were killed by decapitation at various time points, ranging from $2 \mathrm{hr}$ to $6 \mathrm{~d}$ after OBX: every $2 \mathrm{hr}$ during the first $12 \mathrm{hr}$ after lesion and then every $8 \mathrm{hr}$ up to $6 \mathrm{~d}$ (three to four animals per point). Controls were sham-operated mice killed $8 \mathrm{hr}$ after skull drilling. In each animal, the whole bulk of olfactory turbinates ( $30 \mathrm{mg}$ tissular cube wet weight), including the septal tissue and cribriform plate but excluding the respiratory anterior and unfolded region of nasal duct, was dissected out with sterilized, RNase-free tools, frozen in sterile Eppendorf tubes by immersion in liquid nitrogen, and stored at $-80^{\circ} \mathrm{C}$. This tissue sampling is termed "olfactory organ" throughout this paper; it has been devised and validated in several previous studies (Michel et al., 1994, 1997b; Kastner et al., 2000).

For in situ studies, we used LIF knock-out (KO) mice and wild-type (WT) littermates from a colony that was maintained by mating within the original colony of the mutant strain, and by back crossing with the C57BL/6 parental stain (Bugga et al., 1998). Genotyping was done according to Bugga et al. (1998). Mice were subjected to unilateral OBX (removal of only one $\mathrm{OB}$ ) and allowed to survive for either 2 or $5 \mathrm{~d}$ after surgery. Controls consisted of sham-operated animals or the unoperated side of OBX animals. Animals received an intraperitoneal injection of 50 $\mathrm{mg} / \mathrm{kg}$ bromodeoxyuridine (BrdU) (Sigma, St. Louis, MO) $12 \mathrm{hr}$ before animals were killed. They were then anesthetized with pentobarbital (40 $\mathrm{mg} / \mathrm{kg}$, i.p.) (Abbott Labs, Chicago, IL) and perfused transcardially with $4^{\circ} \mathrm{C}$ PBS followed by freshly prepared $4 \%$ paraformaldehyde in PBS at $4^{\circ} \mathrm{C}$. Brains were dissected and checked for complete OBX so that animals with incomplete surgery were not included in the analysis. Olfactory organs were removed and postfixed in the same fixative for $12 \mathrm{hr}$ and cryoprotected in $30 \%$ sucrose in PBS at $4^{\circ} \mathrm{C}$ for $24-48 \mathrm{hr}$, with a 5-10 min step under vacuum. Each olfactory organ was then immersed in Tissue-Tek OCT (Miles, Elkhart, IN) under vacuum for 5-10 min and frozen on dry ice. Coronal sections $(14 \mu \mathrm{m})$ were cut using a cryostat and collected on slides precoated with $0.05 \%$ poly-L-lysine (Sigma), air-dried for $6-12 \mathrm{hr}$, and frozen at $-20^{\circ} \mathrm{C}$ until use. Pairs of adjacent sections were collected for subsequent BrdU immunohistochemistry and terminal deoxynucleotidyl transferase-mediated biotinylated dUTP nick end labeling (TUNEL) staining (see below). For in situ RT-PCR, after fixation as above, olfactory organs were dehydrated and embedded in paraffin; $12-\mu \mathrm{m}$-thick sections were made with a microtome and mounted onto Perkin-Elmer slides (Applied Biosystems, Courtaboeuf, France).

RNA extraction and RT-PCR. Total cellular RNA was extracted from frozen tissues using TRIzol (guanidinium isothyocyanate-acidic phenol) (Life Technologies, Cergy Pontoise, France), following the manufacturer's instructions. Briefly, each sample of frozen tissue was dry-crushed and homogenized in $1 \mathrm{ml}$ of TRIzol. Chloroform $(0.5 \mathrm{ml})$ was added to differentially solubilize RNA. From the aqueous phase, RNA was precipitated with isopropanol (Sigma, Saint Quentin Fallavier, France), washed in $70 \%$ ethanol, and air dried at room temperature. Resulting pellets were resuspended in RNase-free water, and RNA concentrations were determined by absorbance at $260 \mathrm{~nm}$. The semiquantitative method of Estus et al. (1994) was used to measure growth factor and cytokine mRNAs.
Single-stranded cDNAs were obtained from reverse transcription of $3 \mu \mathrm{g}$ of total RNAs in a total volume of $20 \mu \mathrm{l}$ using $10 \mathrm{U} / \mu \mathrm{l}$ of Moloney Murine Leukemia Virus reverse transcriptase (Life Technologies), $5 \mu \mathrm{M}$ random hexanucleotide as primer (Sigma), 0.2 mM dNTP (Life Technologies), 10 $\mu \mathrm{M}$ dithiothreitol, and $1 \times$ manufacturer's RT buffer (Life Technologies). Reaction mixtures were heated for $60 \mathrm{~min}$ at $37^{\circ} \mathrm{C}$ and for $5 \mathrm{~min}$ at $95^{\circ} \mathrm{C}$ and then diluted in water and stored at $-20^{\circ} \mathrm{C}$.

From resulting cDNAs ( $1 \mu \mathrm{l}$ of RT product), sequences of interest were amplified in the same assay for all samples with a thermocycler (M100 MJ-Research, Lyon, France) in a $20 \mu \mathrm{l}$ reaction mixture containing 0.01 $\mathrm{U} / \mu \mathrm{l} \mathrm{Taq}$ polymerase (Promega, Charbonnières, France), manufacturer's Taq buffer, $50 \mu \mathrm{M}$ dNTP (Life Technologies), $0.0375 \mu \mathrm{Ci}$ of $\left[{ }^{33} \mathrm{P}\right]$ dATP (Amersham, Les Ulis, France), $1 \mu \mathrm{M}$ specific primers, and $1.5 \mathrm{~mm}$ $\mathrm{MgCl}_{2}$. Amplification programs included a first step of DNA denaturation $\left(5 \mathrm{~min}\right.$ at $94^{\circ} \mathrm{C}$ ), followed by $18-35$ cycles each comprising DNA denaturation $\left(30 \mathrm{sec}\right.$ at $94^{\circ} \mathrm{C}$ ), primer hybridization (30 sec at primerrespective-temperatures) (Table 1$)$ and elongation $\left(30 \mathrm{sec}\right.$ at $\left.72^{\circ} \mathrm{C}\right)$, and a final elongation step $\left(5 \mathrm{~min}\right.$ at $\left.72^{\circ} \mathrm{C}\right)$. For some primers (BDNF), amplification involved a "hot start," i.e., preliminary heating of the Taq-free reaction mixture for $5 \mathrm{~min}$ at $94^{\circ} \mathrm{C}$ before adding the enzyme and starting the thermocycler program. All oligonucleotides were synthesized by Genset (Paris, France), and their sequences are presented in Table 1.

PCR products were separated by electrophoresis (Protean-2, Biorad, Issy-les-Moulineaux, France) on $8 \%$ polyacrylamide gels, which were then vacuum dried and processed for autoradiography on Biomax films (Kodak, Sevran, France). Exposure times were adjusted to avoid film saturation. For each primer pair, we first determined the optimal hybridization temperature and minimum number of PCR cycles necessary to detect radiolabeled reaction products at a unique, expected molecular size, so that each PCR analysis would be performed in the exponential phase of amplification. Forward and reverse primers were designed in separate exons to avoid any bias caused by residual genomic contamination. PCR-amplified products were checked with restriction enzymes. For all primer pairs, no amplification was observed when PCR was performed on either RNase-free water or non-reverse-transcribed RNA samples. At least three independent PCRs were performed on the same samples for each primer pair.

Optical densities (ODs) of labeled bands on resulting autoradiographs were measured by densitometric scanning using the Bio-Image scanner (Bio-Image, Cheshire, UK). The data were normalized to OD values from $\beta$-actin amplification for the corresponding samples. We then calculated means \pm SEM of the values obtained from animals killed at the same time point, and these ratios were plotted as a function of time. The occurrence of statistically significant differences from controls among the normalized set of data for each mRNA sequence was first addressed by one-way ANOVA using the Instat computer program (Graph Pad software); this first test was taken as positive if the $F$ value yielded a tabulated equivalent for $p<0.05$. Any ANOVA-positive set was further assessed by paired post hoc comparisons in between time points values, as made with the Bonferroni test for multiple comparisons. Differences were accepted as significant when $p<0.05$. Consistent results were obtained from three separate sets of experiments.

Protein extraction and Western blotting. For Western blotting, frozen olfactory organs were homogenized in NP-40 lysis buffer, i.e., $0.5 \%$ Nonidet $\mathrm{P} 40$ in $50 \mathrm{~mm}$ Tris, pH 8.0, containing (in $\mathrm{mm}$ ): $120 \mathrm{NaCl}, 0.1 \mathrm{NaF}$, $0.1 \mathrm{Na}_{3} \mathrm{VO}_{4}, 1$ EDTA, and 1 protease inhibitor mixture (Roche Diagnostics, Meylan, France). After $1 \mathrm{hr}$ at $4^{\circ} \mathrm{C}$ with agitation, lysates were cleared by centrifugation at $10,000 \times g$ for $15 \mathrm{~min}$ and frozen. After protein quantitation by Bradford assay, lysates were diluted in NP-40 buffer to a concentration of $8 \mathrm{mg} / \mathrm{ml}$, mixed with equal volumes of $2 \times$ protein sample buffer, boiled for $5 \mathrm{~min}$, and kept frozen until use. Electrophoresis was performed on SDS-9\% polyacrylamide mini-gels (Mini-Protean system, Biorad) after loading $20 \mu \mathrm{g}$ of protein (i.e., $5 \mu \mathrm{l}$ of NP-40 extract) in each lane (Laemmli, 1970). After electrotransfer to nitrocellulose membrane (Optitran BAS 85; Schleicher \& Schuell, Ecquevilly, France), blots were blocked for $2 \mathrm{hr}$ in a 5\% skim milk solution and incubated overnight at $4^{\circ} \mathrm{C}$ with primary antibodies against LIF (polyclonal, 1:100; Santa-Cruz, Tebu, Le Perray, France) and $\beta$-actin (monoclonal, 1:6000; Roche Diagnostics) in the same buffer. After $1 \mathrm{hr}$ incubation in appro- 
Table 1. Summary of the protocol used for the semiquantitative RT-PCR approach, including primer sequences (forward and reverse), the expected product size (bp), the concentration of $\mathrm{MgCl}_{2}\left(\left[\mathrm{Mg}^{2+}\right]\right.$, in $\left.\mathrm{mM}\right)$, the annealing temperature $\left({ }^{\circ} \mathrm{C}\right)$, the number of $\mathrm{PCR}$ cycles, the reference when primer sequences have been already used, and/or the GenBank accession number

\begin{tabular}{|c|c|c|c|c|c|c|}
\hline Gene & $\begin{array}{l}\text { Sequence }\left(5^{\prime}-3^{\prime}\right) \\
\text { (forward and reverse) }\end{array}$ & $\begin{array}{l}\text { Product } \\
\text { size (bp) }\end{array}$ & {$[\mathrm{Mg} 2+](\mathrm{mm})$} & $\begin{array}{l}\text { Annealing } \\
\text { temperature }\left({ }^{\circ} \mathrm{C}\right)\end{array}$ & $\begin{array}{l}\text { Number of } \\
\text { cycles }\end{array}$ & $\begin{array}{l}\text { Reference/GenBank accession } \\
\text { number }\end{array}$ \\
\hline \multirow[t]{2}{*}{$\beta$-actin } & GACAGGATGCAGAAGGAGAT & & & & & \\
\hline & TTGCTGATCCACATCTGCTG & 146 & 1.5 & 62 & 18 & Michel et al. (1994)/X03765 \\
\hline \multirow[t]{2}{*}{ OMP } & GACATTCTTCTAGCTGCTCC & & & & & \\
\hline & CAGCTTTGGCCAGCAGGG & 354 & 2 & 63 & 20 & Krishna et al. (1966)/U01213 \\
\hline \multirow[t]{2}{*}{ LIF } & CAGCCCATAATGAAGGTCTTGGC & & & & & \\
\hline & TGCCATTGAGCTGTGCCAGTTG & 184 & 1.5 & 59 & 25 & Michel et al. (1997a)/M63419 \\
\hline \multirow[t]{2}{*}{ LIF-R } & GGAGAAAGGTTCCTTCAAACAGCAC & & & & & \\
\hline & CTCAGTGTCTTCTGGGATATGTCAG & 370 & 1.5 & 59 & 23 & D26177 \\
\hline \multirow[t]{2}{*}{ EGF } & CCAGTTCAGTAGAAACTGGG & & & & & \\
\hline & TGGTTTCTAATGATTTTCTC & 248 & 1.5 & 53 & 25 & V00741 \\
\hline \multirow[t]{2}{*}{$\mathrm{TGF} \alpha$} & ACCTGCCGGTTTTTGGTGCAG & & & & & \\
\hline & ATGTCTGCAGACGAGGGCACG & 246 & 1.5 & 62 & 25 & U65016 \\
\hline \multirow[t]{2}{*}{ EGF-R } & GGAGGAAAAGAAAGTCTGCC & & & & & \\
\hline & CCCATAGTTGGATAGGATGG & 304 & 1.5 & 63 & 24 & Krishna et al. (1966)/X59698 \\
\hline \multirow[t]{2}{*}{ TGF $\beta 1$} & TGACGTCACTGGAGTTGTACG & & & & & \\
\hline & CTCGTGGATCCACTTCCAAC & 346 & 1.5 & 59 & 25 & AJ009862 \\
\hline \multirow[t]{2}{*}{$\operatorname{TGF} \beta 2$} & ATGCACTACTGTGTGCTGAGC & & & & & \\
\hline & CTTCAGCTTGCTCAGGATCTG & 147 & 1.5 & 59 & 25 & $X 57413$ \\
\hline \multirow[t]{2}{*}{ TGF $\beta 3$} & TTCAATGTGTCCTCAGTGGAG & & & & & \\
\hline & ATGGTCATCTTCATTGTCCAC & 378 & 1.5 & 59 & 25 & M32745 \\
\hline \multirow[t]{2}{*}{ TGF $\beta$-R1 } & ACATGGACGCAGCTGTGCTTG & & & & & \\
\hline & CACCAATAGAACAGCGTCGAG & 442 & 1.5 & 59 & 22 & D28526 \\
\hline \multirow[t]{2}{*}{ TGF $\beta-R 3$} & TTCACCGAACTCAAGATAGC & & & & & \\
\hline & TTGATCACCCAGTTGACAGA & 332 & 1.5 & 59 & 25 & AF039601 \\
\hline \multirow[t]{2}{*}{ FGF2 } & GCCAGCGGCATCACCTCGCT & & & & & \\
\hline & TATGGCCTTCTGTCCAGGTCCCGT & 429 & 1.5 & 59 & 25 & Ozawa et al. (1997)/M30644 \\
\hline \multirow[t]{2}{*}{ BDNF } & CCAGAGCAGCTGCCTTGATG & & & & & \\
\hline & GAGGCTCCAAAGGCACTTGAC & 389 & 1.5 & 59 & 25 & X55573 \\
\hline
\end{tabular}

priate peroxidase-linked secondary antibodies (Amersham), immunoreactivity was detected by chemoluminescence (ECL, Amersham).

$B r d U$ immunohistochemistry. Frozen, prefixed sections were brought to room temperature, hydrated for $5 \mathrm{~min}$ in $0.01 \mathrm{M}$ sodium citrate buffer, $\mathrm{pH} 5.5$, and incubated in the same buffer for $20 \mathrm{~min}$ at $98-100^{\circ} \mathrm{C}$ to denature endogenous DNA. Sections were then dried at room temperature, rinsed in PBS, and treated for 2 min with pepsin (Sigma), 0.25 $\mathrm{mg} / \mathrm{ml}$ in $0.1 \mathrm{~N} \mathrm{HCl}$ to unmask DNA. After three 5 min rinses in PBS, sections were incubated in $3 \% \mathrm{H}_{2} \mathrm{O}_{2}$-containing PBS for $20 \mathrm{~min}$, rinsed in PBS, and incubated for 30 min in PBS containing 0.125\% BSA, $0.05 \%$ Triton X-100, and 2.5\% normal goat serum. Sections were then incubated with the anti-BrdU antibody (rat monoclonal, Harlan Sera-Lab, Loughborough, UK) diluted 1:100 in PBS containing 0.125\% BSA and $0.05 \%$ Triton X-100 for $3 \mathrm{hr}$ at room temperature. After three $10 \mathrm{~min}$ PBS rinses, sections were further incubated in biotinylated anti-rat immunoglobulin antibody (Vector Laboratories, Burlingame, CA) diluted 1:200 in PBS for $2 \mathrm{hr}$ at room temperature. After three 10 min PBS rinses, sections were incubated with avidin-peroxidase mixture (Elite-ABC kit, Vector Laboratories) for $30 \mathrm{~min}$ at room temperature. After rinsing two times for $10 \mathrm{~min}$ each in PBS and once in $0.05 \mathrm{~m}$ Tris- $\mathrm{HCl}, \mathrm{pH} 7.6$, tissue-bound peroxidase was visualized by $10 \mathrm{~min}$ incubation in $50 \mathrm{~mm}$ Tris, $\mathrm{pH}$ 7.6, containing $0.05 \% \mathrm{DAB}, 0.03 \% \mathrm{NiCl}_{2}$, and $0.6 \% \mathrm{H}_{2} \mathrm{O}_{2}$. Sections were then treated with ethanols (70, 95, 100\%; two times for 5 min each) and xylene (10 min) and coverslipped with DEPEX (Merck, Isle d'Abeau, France).

TUNEL staining. Apoptotic nuclei were labeled in situ by the TUNEL method (Gavrieli et al., 1992). Frozen sections of fixed tissue were brought to room temperature, rinsed $15 \mathrm{~min}$ in PBS, and treated overnight with $0.1 \%$ Triton X-100 (Sigma) in PBS to unmask DNA; this step replaces the usual $2-5$ min treatment with proteinase $\mathrm{K}$, because it was found to yield the same sensitivity with improved tissue preservation (Martin-Villalba et al., 1999). After a 10 min rinse in PBS, sections were treated for 10 min with $3 \% \mathrm{H}_{2} \mathrm{O}_{2}$ in PBS to block endogenous peroxi- dases. After PBS rinsing, sections were preincubated in TdT buffer (30 mM Tris, $\mathrm{pH} 7.5$, containing $140 \mathrm{~mm}$ sodium cacodylate and $1 \mathrm{~mm}$ cobalt chloride). Sections were then drop-incubated in TdT buffer containing $300 \mathrm{U} / \mathrm{ml} \mathrm{TdT}$ (Roche Diagnostics) and $6 \mu \mathrm{m}$ biotinylated dUTP (Roche Diagnostics) in a humid chamber for $90 \mathrm{~min}$ at $37^{\circ} \mathrm{C}$; the reaction was stopped by a $15 \mathrm{~min}$ rinse at room temperature in TB buffer $(300 \mathrm{~mm}$ $\mathrm{NaCl}, 30 \mathrm{~mm}$ sodium citrate). Sections were rinsed again in PBS before a 10 min treatment with BSA (bovine serum albumin fraction V, Sigma) at $2 \%$ in PBS to minimize nonspecific staining. After one PBS rinse, biotindUTP-labeled sections were incubated with avidin-peroxidase mixture (Elite-ABC kit, Vector Laboratories) for $30 \mathrm{~min}$ at room temperature. After rinsing twice in PBS and once in $50 \mathrm{~mm}$ Tris, $\mathrm{pH} 7.5$, tissue-bound peroxidase was visualized by $5 \mathrm{~min}$ incubation in $50 \mathrm{~mm}$ Tris, $\mathrm{pH}$ 7.6, containing $0.05 \% \mathrm{DAB}, 0.03 \% \mathrm{NiCl}_{2}$, and $0.6 \% \mathrm{H}_{2} \mathrm{O}_{2}$. Sections were then dehydrated in graded ethanols $\left(70,95,100^{\circ}\right.$; two times for $5 \mathrm{~min}$ each) and xylene (10 min) and coverslipped with DEPEX.

Labeling quantification. Stained BrdU- or TUNEL-positive nuclei were quantified on adjacent sections, using computer-assisted densitometry and morphometry (Historag 8 software, Biocom, Les Ulis, France). Analysis was performed blinded to the animal origin (genotype and post-OBX survival time) at two different rostrocaudal levels of the olfactory organ that were the same in all animals. Labeled nuclei were scored manually in the septal OE. For inter-animal comparison, nuclei numbers were normalized over the linear length of epithelium used for quantification, as measured with the Biocom system (arbitrary units). A total of 120 slides was analyzed. For each staining, at least five sections per animal were analyzed, corresponding to $>4 \mathrm{~mm}$ length of septal OE per animal. Results were expressed as mean \pm SEM of the total number of positive nuclei over the total linear length of $\mathrm{OE}$ for each treatment group (four to five animals per group). Intergroup differences were assessed statistically by Student's $t$ test and considered significant when $p<0.05$.

Olfactory marker protein in situ hybridization. In situ hybridization (ISH) was performed under RNase-free conditions according to the 


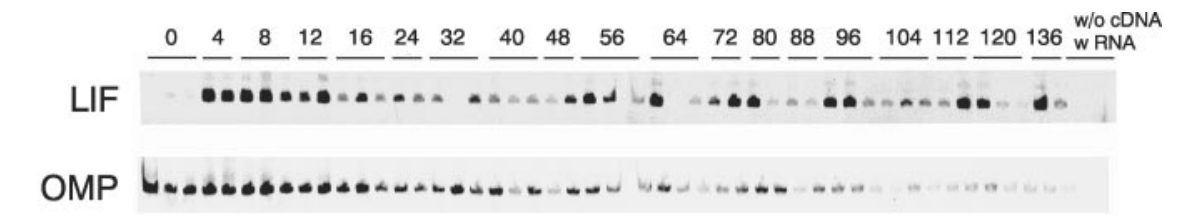

$\beta$-actin

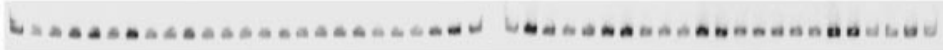

Figure 1. LIF $m R N A$ is induced and OMP mRNA disappears after OBX. Autoradiograms are shown of typical RT-PCR data obtained from total olfactory organ RNA from one series of adult mice. Each band corresponds to one animal killed at the delay indicated on top (in hours) after bilateral OBX. Control tubes were included in each experiment, either without retrotranscribed RNA (without CDNA) or with purified RNAs instead of the CDNAs (with RNA). The sequences amplified are indicated on the left: $\beta$-actin as internal control, olfactory marker protein (OMP), and leukemia inhibitory factor (LIF).

protocol of Jankowsky and Patterson (1999) with a few modifications. Digoxigenin-labeled antisense and sense RNA probes were generated from a 517 bp olfactory marker protein (OMP) cDNA plasmid, using an in vitro transcription kit (Roche Diagnostics). DNA from the reaction was removed before probe purification. Purified probes were subjected to Agarose gel electrophoresis to confirm probe integrity, and concentrations were determined by spectrophotometry.

Frozen sections were fixed by rapid immersion in ice-cold $4 \%$ paraformaldehyde for $20 \mathrm{~min}$, rinsed in PBS, and treated with $2 \mu \mathrm{g} / \mathrm{ml}$ proteinase $\mathrm{K}$ (Roche Diagnostics) in $20 \mathrm{~mm}$ Tris, $\mathrm{pH} 7.5,2 \mathrm{~mm} \mathrm{CaCl}_{2}$, for 10 $\mathrm{min}$ at room temperature. Sections were rinsed and refixed in $4 \%$ paraformaldehyde for $10 \mathrm{~min}$ to inactivate the proteinase $\mathrm{K}$. Sections were then rinsed and acetylated in acetic anhydride for $10 \mathrm{~min}$, rinsed again, and dehydrated in graded ethanols (70, 95, 100\%). Air-dried sections were incubated in hybridization buffer containing $10 \%$ dextran sulfate, $50 \%$ formamide, $4 \times$ SSC, $100 \mu \mathrm{g} / \mathrm{ml}$ tRNA, $100 \mu \mathrm{g} / \mathrm{ml}$ ssDNA, $1 \times$ Denhardt's solution, with $1 \mu \mathrm{g} / \mathrm{ml}$ probe overnight at $60^{\circ} \mathrm{C}$. Sections were washed several times in graded SSC at $50^{\circ} \mathrm{C}$. They were then blocked with $1 \%$ normal goat serum in PBS for $30 \mathrm{~min}$, followed by incubation in anti-digoxigenin antibody conjugated with alkaline phosphatase (Roche Diagnostics) diluted 1:1500 in the same buffer for $2 \mathrm{hr}$ at room temperature. After several washes in PBS, staining was visualized using nitroblue tetrazolium and 5-bromo 4-chloro 3-indolyl phosphate (Roche Diagnostics) in $100 \mathrm{~mm}$ Tris, $100 \mathrm{~mm} \mathrm{NaCl}, 50 \mathrm{~mm} \mathrm{MgCl}_{2}, \mathrm{pH} 9.6$.

In situ RT-PCR. Indirect in situ RT-PCR was performed as described previously (Recher et al., 2001). Briefly, dewaxed sections treated with proteinase $\mathrm{K}$ were dehydrated and air dried. In situ $\mathrm{RT}$ reaction buffer contained $50 \mathrm{~mm}$ Tris, pH 7.4, $75 \mathrm{~mm} \mathrm{KCl,} 10 \mathrm{~mm}$ dithiothreitol, $3 \mathrm{~mm}$ $\mathrm{MgCl}_{2}, 0.5 \mathrm{~mm}$ dNTP, $1 \mu \mathrm{M}$ antisense primer, $1 \mathrm{U} / \mu \mathrm{l}$ RNase inhibitor, and $10 \mathrm{U} / \mu \mathrm{l}$ SuperScript II (Life Technologies). The sections were covered with $40 \mu \mathrm{l}$ of the reaction buffer, sealed with amplicover clips, and incubated at $42^{\circ} \mathrm{C}$ for $1 \mathrm{hr}$. Coverslips were removed and sections were washed in $0.1 \mathrm{M}$ phosphate buffer, dehydrated, and air dried. In situ PCR reaction buffer contained $10 \mathrm{~mm}$ Tris, $50 \mathrm{~mm} \mathrm{KCl}, 1.5 \mathrm{mM} \mathrm{MgCl}_{2}, 0.5 \mathrm{~mm}$ dNTP, $1 \mu \mathrm{M}$ each primer, and $0.2 \mathrm{U} / \mu \mathrm{l}$ TaqDNA polymerase (Eurobio, Les Ulis, France). The sections were covered with $40 \mu \mathrm{l}$ of this reaction buffer, sealed, and placed on a Perkin-Elmer thermal cycler (Applied Biosystems). A total of 25 PCR cycles were performed under the same conditions as for liquid PCR. Sections were then fixed with $4 \%$ paraformaldehyde (15 $\mathrm{min}$ ) and washed as described in the ISH procedure. The sections were then hybridized as described above overnight at $40^{\circ} \mathrm{C}$, with 30 pmol of probes per milliliter after 3 min denaturation at $94^{\circ} \mathrm{C}$, using 30 mers sense (CTTACTGCTGCTGGTTCTGCACTGGAAACA) and antisense (TTCTTGATCTGGTTCATGAGGTTGCCGTGG) oligonucleotides (Genset) labeled with digoxigenin-11-dUTP by $3^{\prime}$ extension using terminal transferase (Roche Diagnostics) and then ethanol purified. Washing steps were done in $2 \times$ SSC (two times for $30 \mathrm{~min}$ ), $0.5 \times$ SSC (30 $\mathrm{min}$ ) at room temperature, and hybrid detection as described above. Several controls were performed: (1) ISH only, (2) omission of the ISH, (3) omission of the reverse transcriptase, and (4) omission of the TaqDNA polymerase.

LIF immunohistochemistry. LIF immunohistochemistry was performed using a goat polyclonal anti-mouse LIF antibody (R \& D Systems,
Minneapolis, MN) as primary antibody, followed by biotin-conjugated anti-goat raised in horse (Vector Laboratories) as secondary antibody. Frozen sections were hydrated in PBS, incubated in $3 \% \mathrm{H}_{2} \mathrm{O}_{2}$ for $10 \mathrm{~min}$ at room temperature and then in $0.1 \%$ Triton $\mathrm{X}-100$ for 5 min at room temperature, and blocked with $2 \%$ normal horse serum diluted in PBS for $2 \mathrm{hr}$ at room temperature. Primary antibody diluted 1:100 was incubated overnight at $4^{\circ} \mathrm{C}$ in the same buffer. After several washes in PBS, secondary antibody diluted 1:200 was incubated in PBS containing 2\% normal horse serum for $90 \mathrm{~min}$ at room temperature. After several washes in PBS and blocking in 2\% BSA in PBS for $10 \mathrm{~min}$ at room temperature, sections were incubated in Elite-ABC kit (Vector Laboratories), and staining was visualized with $\mathrm{DAB} / \mathrm{NiCl}_{2}$ as described above.

Adenoviral delivery of LIF. Recombinant LacZ and LIF adenoviruses were prepared and assayed as described previously (Zhu et al., 2001) Virus $\left(10^{-7} \mathrm{pfu}\right)$ was administered to anesthetized adult mice (xylazine/ ketamine) in $50 \mu$ l of culture medium (plus $2 \%$ fetal bovine serum) using a Hamilton syringe inserted $1 \mathrm{~cm}$ into the right nostril, while the animal lay on its left side, at a rate of $0.6 \mu \mathrm{l} / \mathrm{min}$. Control mice received saline without virus. To visualize viral infection and transgene expression in the OE, mice were killed $5.5 \mathrm{~d}$ later and perfused with $4 \%$ paraformaldehyde, and frozen sections were prepared. Sections were stained either with a goat anti-mouse LIF IgG (R \& D Systems) and a fluorescent-labeled, swine anti-goat secondary antibody (Roche Diagnostics, Indianapolis, IN) or for LacZ (Roche Diagnostics).

To study cell death, mice were killed $5.5 \mathrm{~d}$ after viral infection, and $\mathrm{OE}$ sections were stained for TUNEL, as described above. TUNEL-positive cells were counted in the entire OE of the injected side from 10 sections for two mice of each type (control, LacZ and LIF adenovirus). To assess neurogenesis, mice were injected with $50 \mathrm{mg} / \mathrm{kg}$ BrdU $5 \mathrm{~d}$ after infection and killed 6 or $12 \mathrm{hr}$ later. BrdU was visualized as described above, and labeled cells were quantified as for TUNEL. Separate counts were made for the apical and basal layers of the OE, and statistical analysis was performed with Student's $t$ test. Inter-group differences were considered significant when $p<0.05$.

\section{Results \\ LIF mRNA is selectively induced in the olfactory organ after bulbectomy}

Because mitogens are often regulated at the transcriptional level, we assayed changes in mRNA levels of candidate mitogens after OBX using semiquantitative RT-PCR (Estus et al., 1994). Extracts of whole olfactory organs from OBX mice have been used successfully to analyze molecular events in apoptosis (Michel et al., 1994, 1997b; Farbman et al., 1999; Suzuki and Farbman, 2000), cell cycle control (Kastner et al., 2000), and signal transduction (Ezeh and Farbman, 1998). In the present study, artifacts were minimized by (1) optimization of each PCR protocol to generate products of the expected molecular size, (2) restriction enzyme analysis of these products, and (3) systematic assessment of negative controls in each PCR assay (data not shown). The signals yielded by the RT-PCR amplification of $\beta$-actin RNA from olfactory organs sampled at various times after lesion were fairly constant (Fig. 1) and therefore were used as a reference for the semiquantitative normalization of other RT-PCR products. Resulting kinetics of mRNA expression after OBX were validated by several observations, including (1) kinetics of the decline in OMP after OBX (Figs. 1, 2) being consistent with previously documented timing of OBX-induced OSN degeneration (Schwartz-Levey et al., 1991; Michel et al., 1994), (2) the duplication of kinetics of c-fos mRNA expression (data not shown) found in a previous 
RT-PCR study in the same murine strain using a different primer pair (Michel et al., 1994), and (3) the diversity of expression time courses among the 13 genes assayed (Fig. 2).

Most of the cytokines and growth factors assessed (EGF, TGF $\alpha$, TGF $\beta 1, \beta 2$, $\beta 3$, FGF2) are already expressed in the olfactory organ before surgery (Fig. 2). In contrast, LIF (Fig. 1) and BDNF (Fig. 2) are barely detectable in the controls. Although expression levels of all of these growth factors and cytokines show slight variations after OBX, we find that LIF is the only factor with levels that are significantly increased after OBX and before the onset of progenitor cell proliferation (Schwartz-Levey et al., 1991; Bauer et al., 2000) (Fig. 2). This induction is rapid, appearing to peak $8 \mathrm{hr}$ after the lesion ( $p<$ $0.01)$. LIF induction is transient, declining to nonsignificant values by $1 \mathrm{~d}$ after OBX, although LIF signal shows apparently nonsignificant fluctuations at later time points.

Among the four receptor mRNAs that were assessed, the LIF receptor (LIFR) is also the only one to display upregulation after OBX (Fig. 2) ( $p=0.078)$. This signal then decreases by 3-6 d (Fig. 2) $(p<$ 0.05 ), a time corresponding to the maximum progenitor cell proliferation in the OE after OBX (Schwartz-Levey et al., 1991).

\section{OBX induces LIF protein}

To determine whether LIF mRNA induction results in the in vivo synthesis of LIF protein, we monitored LIF protein expression by immunoblotting whole extracts of olfactory organs from bulbectomized mice (Fig. 3). In the control olfactory organ, LIF protein is not detectably expressed. After OBX, LIF protein accumulates quickly, reaching maximal levels $4-8 \mathrm{hr}$ after lesion and then gradually decaying by $24 \mathrm{hr}$. Levels of $\beta$-actin remain constant over time on the same blots (Fig. 3).

Thus, OBX-induced LIF mRNA induction is paralleled by an accumulation of LIF protein in the olfactory organ. The lack of a delay between mRNA and protein upregulation as well as the absence of internal stores of mature signal are characteristic features of growth factor/neurotrophin production (cf. pulse-chase analysis of NGF secretion) (Mowla et al., 1999).

\section{OBX induces LIF in mature olfactory neurons}

To identify cells that upregulate LIF mRNA after OBX, we used in situ RT-PCR for LIF mRNA and immunocytochemistry for LIF protein. In the OE, as seen $8 \mathrm{hr}$ after unilateral OBX, LIF mRNA signal is primarily found in cell bodies of the medial region of the OE (Fig. $4 A, B$ ). These correspond to OMP-expressing perikarya of OSNs, as visualized by conventional in situ hybridization on adjacent sections (Fig. 4D). However, LIF mRNA signal is also detected in the sustentacular cell layer and in the basal compartment of the OE, and some sparse labeled cells are found in the lamina propria beneath the $\mathrm{OE}$ (Fig. $4 A, B$ ). No signal is observed on the unoperated, contralateral side of olfactory organ sections
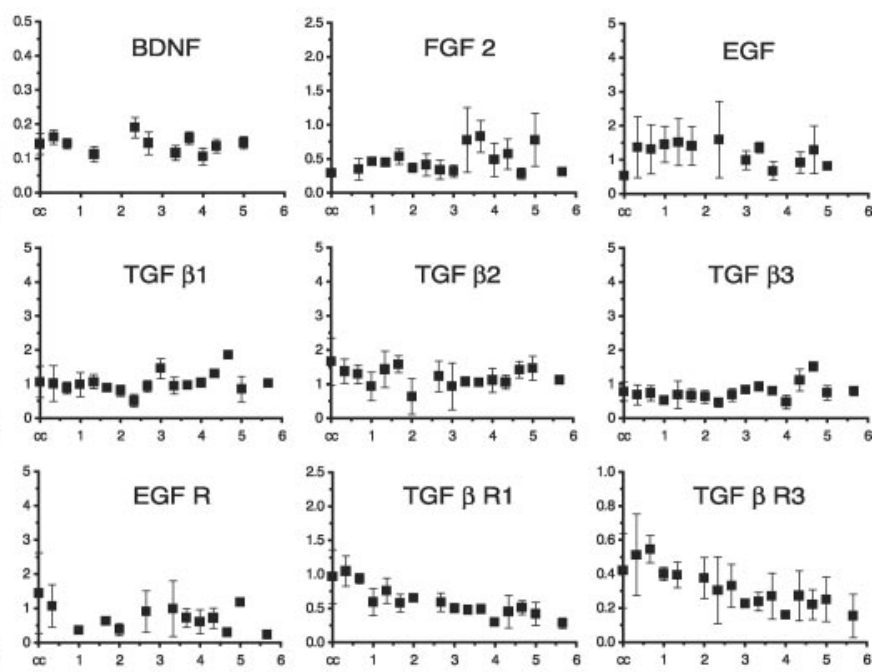

Days after bulbectomy

Figure 2. Expression kinetics of candidate mitogens and receptors in the olfactory organ of adult mice after OBX. Semiquantitative RT-PCR data are expressed as ratios to $\beta$-actin mRNA for each sample, which were averaged as a function of time after lesion 列 significant variation of $\mathrm{mRNA}$ expression is detected in this paradigm.

or on sections from intact mouse olfactory organ (data not shown), consistent with the very low level of mRNA expression found in control mice olfactory organs with our semiquantitative RT-PCR approach (Fig. 1).

Consistent with the localization of LIF mRNA signal in the neuronal layer of the OE, $8 \mathrm{hr}$ after OBX, LIF immunoreactivity is found in olfactory axon bundles in the lamina propria that underlies the OE (Fig. 4E). No staining is observed on the unoperated, contralateral side of olfactory organ sections (Fig. $4 F$ ).

Taken together, these results indicate that OBX-triggered synthesis of LIF occurs in the mature OSN population. Because most of the OSNs are committed to apoptosis by OBX (see Introduction), this observation suggests that the dying neurons upregulate LIF $8 \mathrm{hr}$ after OBX in the adult mouse OE. This hypothesis cannot be assessed directly because the earliest apoptosis markers in OSNs become detectable $16 \mathrm{hr}$ after OBX (Michel et al., 1994, 1997b), when LIF mRNA levels are returning to baseline (see above). In addition, other cell types, such as sustentacular, basal, or ensheathing glial cells, could also be involved in LIF synthesis after OBX.

\section{Neurogenesis and cell death in the absence of LIF}

To investigate the biological significance of LIF signaling in vivo in the OE, we analyzed the effects of OBX on apoptosis (TUNEL staining) and proliferation (acute BrdU incorporation) in the $\mathrm{OE}$ of LIF KO mice compared with WT littermate controls. Labeling quantification was done by an observer blind to the experimental conditions and consisted of manually scoring positive cell profiles (TUNEL or BrdU) in the septal OE. The data are expressed as labeling indices for TUNEL and BrdU staining: the ratio of the 


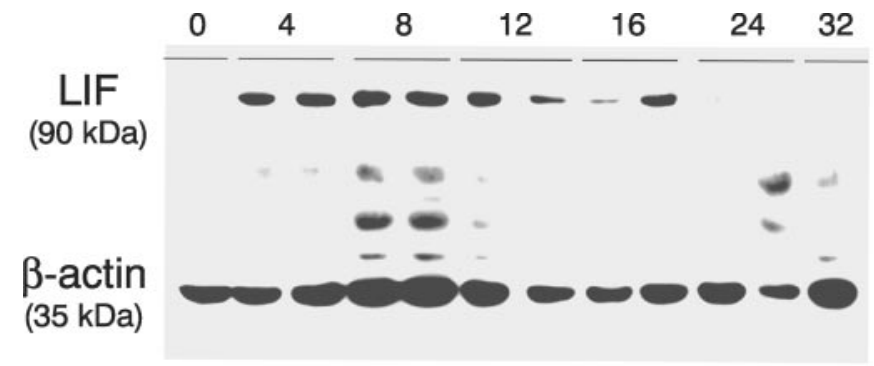

Figure 3. LIF protein is induced by OBX. Western blots were performed for LIF and $\beta$-actin on extracts from olfactory organs sampled at various times (hours, indicated on top) after bilateral OBX. Duplicate samples from two independent mice are shown for each OBX time point. LIF mobility is known to vary according to carbohydrate composition; in this preparation the LIF band is $\sim 90 \mathrm{kDa}$. This band only appears after OBX and is obvious at the earliest time point (4 $\mathrm{hr}$ after OBX). LIF signal is no longer apparent at $24 \mathrm{hr}$. The identity of the other bands is not known, but they are apparent without the LIF primary antibody, unlike the $90 \mathrm{kDa}$ band.

total number of positive cells to the linear length of septal OE analyzed. This type of quantification has been used previously by a number of investigators, as stereological analysis cannot be used in this system because of the variations in OE thickness induced by OBX (Schwartz-Levey et al., 1991; Holcomb et al., 1995).

Five days after OBX, the number of BrdU-labeled cells is significantly increased over sham controls by 2.6 -fold in the OE of WT mice (Fig. $5 A)(p=0.001)$, consistent with previously reported effects of OBX (Schwartz-Levey et al., 1991). In contrast, the number of BrdU-labeled cells in the OE of LIF $\mathrm{KO}$ mice is identical to that in the sham animals (Fig. $5 \mathrm{~A})(p=$ 0.43 ). Therefore, the induction of proliferation $5 \mathrm{~d}$ after OBX does not occur in the absence of LIF. Moreover, the difference in the number of BrdU-labeled cells between WT and LIF KO animals $5 \mathrm{~d}$ after OBX is highly significant $(p=0.003)$ and is similar to that in WT mice when comparing the $5 \mathrm{~d}$ OBX and the sham animals (Fig. 5A).

Interestingly, $2 \mathrm{~d}$ after OBX the number of BrdU-labeled cells in the WT compared with the sham significantly decreases (Fig.

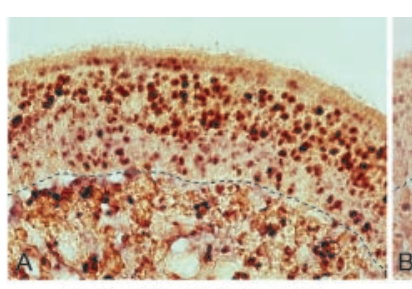

LIF in situ RT-PCR : LIF+

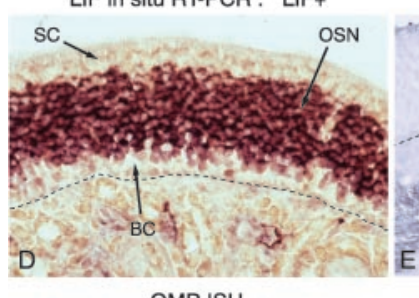

OMP ISH

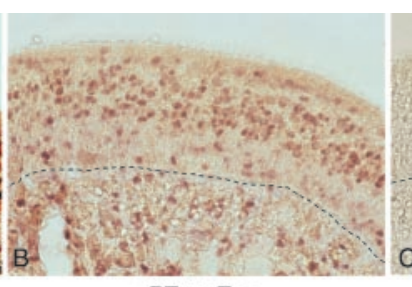

+RT, no Taq

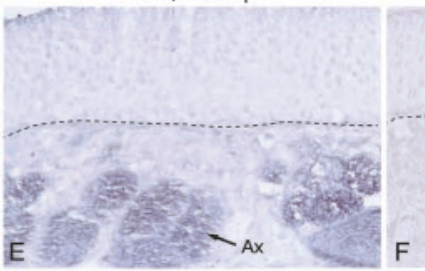

LIF IHC (8 Hr. post-OBX)

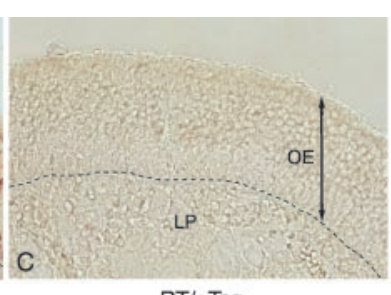

$-\mathrm{RT} /+\mathrm{Taq}$

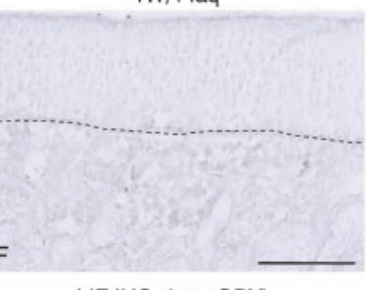

LIF IHC (non-OBX)
Figure 4. In situ localization of LIF in the olfactory mucosa. $A$, Using indirect in situ RT-PCR, LIF mRNA expression $8 \mathrm{hr}$ after unilateral $O B X$ is found mainly in the olfactory epithelium $(O E)$. $B$, Signal density is decreased when the reaction is restricted to reverse transcription by omission of the Taq polymerase. In both cases $(A, B)$, some labeled cells are found in the sustentacular cell $(S C)$ and the basal cell $(B C)$ layers, and in the lamina propria $(L P)$, under the $O E$ (basal lamina is indicated by the dashed line). $C$, When reverse transcription is omitted, no signal can be detected. $D$, Perikarya of olfactory sensory neurons (OSN) were identified on adjacent sections using classical in situ hybridization for OMP mRNA, which is a specific marker for terminally differentiated OSNs (Margolis, 1982). E, F, LIF protein is localized using immunostaining. E, Transverse section of OE $8 \mathrm{hr}$ after unilateral OBX shows specific labeling localized in olfactory axon bundles $(A x)$ of ipsilateral septum. $F$, No significant signal is found in contralateral, uninjured mucosa. Scale bar, $50 \mu \mathrm{m}$.
$5 B)(p=0.04)$ and, to a greater extent, in the LIF KO animals significantly decreased in the LIF KO animals compared with the $2 \mathrm{~d}$ after OBX (Fig. 5B) $(p=0.01)$

cell death, OBX also induces a $>500$-fold increase sham controls). These results are consistent with earlier reports demonstrating OBX-induced neuronal cell death in the OE of adult mice (Michel et al., 1994; Holcomb et al., 1995). (n) however (Fig. 6A) ( $p=0.1$ ). dy-state level of basal cell proliferation (Schwartz-Levey (Figs 5,6 ). This is consistent with the histological organization the normal adult $\mathrm{OE}$ being similar in both genotypes (data not

\section{Exogenous LIF induces neurogenesis and apoptosis} effective in causing transgenic expression of either LacZ or LIF in skin (Zhu et al., 2001), we unilaterally injected the nostrils of unoperated WT mice with either virus. All analyses were performed $5 \mathrm{~d}$ after viral infection. At this time point, LacZ and exogenous LIF expression are detected in the $\mathrm{OE}$ (Fig. $7 \mathrm{~B}, \mathrm{C}$ ). Infection, detection, and transgene expression are more effective with the LacZ than the LIF virus (Table 2). Nonetheless, both vectors are very effective in inducing transgene expression in this system.

Comparing OE from infected versus noninfected mice, we found that LIF overexpression leads to a $40 \%$ reduction of $\mathrm{OE}$ thickness ( $p=0.01)$, an effect not seen with LacZ adenovirus or with sham infection (Table 2). Hypothesizing that thinning of the OE after LIF adenovirus infection could be caused by cell death, we determined the effects of exogenous LIF expression on TUNEL staining in the OE of uninjured, WT mice. The shaminfected and LacZ-expressing OEs display very few TUNEL-positive cells (Fig. $7 D, E)$, indicating an absence of toxicity from adenovirus administration in these conditions. In contrast, the OE expressing exogenous LIF displays strong TUNEL staining in both apical and basal cellular layers (Fig. 7F). Quantification reveals a 90-fold increase in TUNEL-positive cells in 

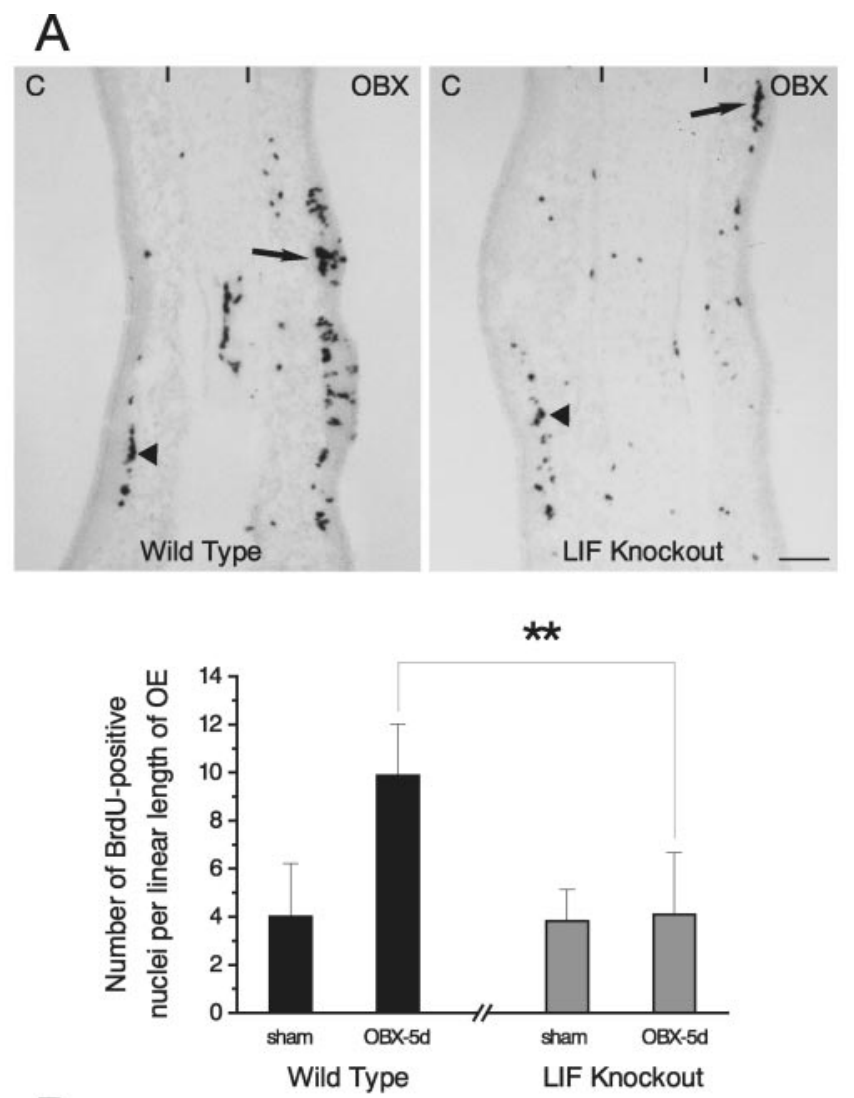

B

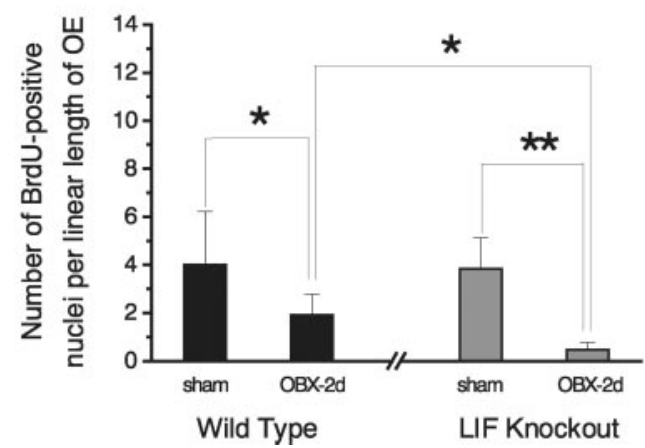

Figure 5. LIF is required for the induction of BrdU labeling in OE after OBX. $A$, Typical sections of the olfactory organ, through the cartilaginous septum (between the two markers at the top of the photographs), are shown stained for BrdU at the peak of proliferation, $5 \mathrm{~d}$ after unilateral OBX. When comparing BrdU staining in the septal OE of LIF KO mice and WT littermates, it is clear that proliferation is induced by $O B X(O B X$, arrows) in the WT OE but not in the LIF KO OE. Cell proliferation in the nonoperated $\mathrm{OE}(C$, arrowheads) is similar for both genotypes. These results were quantified by assessing the number of BrdU-labeled nuclei per linear length of septal $\mathrm{OE}$ (arbitrary units) at the peak of proliferation, $5 \mathrm{~d}$ after OBX or sham operations, as shown in the graph $(A)$. The basal level of BrdU labeling indicated by the sham values does not differ between the genotypes. Although BrdU labeling is strongly increased (245\% over sham) after OBX in the WT, there is no significant increase in the LIF KO ( $8 \%$ over sham). The difference in BrdU labeling between the genotypes at this time point is highly significant $\left.{ }^{* *} p=0.003\right)$. $B$, The same analysis was performed $2 \mathrm{~d}$ after OBX. Interestingly, cell proliferation is significantly decreased compared with sham controls in both the LIF KO mice and WT littermates $\left({ }^{* *} p=0.003\right.$ and ${ }^{*} p=0.04$, respectively). Moreover, proliferation is even more reduced in the LIF KO mice ( ${ }^{*} p=0.01$ when compared with WT value at $2 \mathrm{~d}$ ). All statistical analysis was performed with Student's $t$ test. Scale bar, $100 \mu \mathrm{m}$.

LIF virus-infected mice (counting all layers of the OE) $(p<0.0001)$ (Table 2).

To further analyze the effects of exogenous LIF on cell turnover, we assessed proliferation by injecting BrdU $5 \mathrm{~d}$ after viral infection (OBX-induced proliferation peaks $5 \mathrm{~d}$ after lesion in
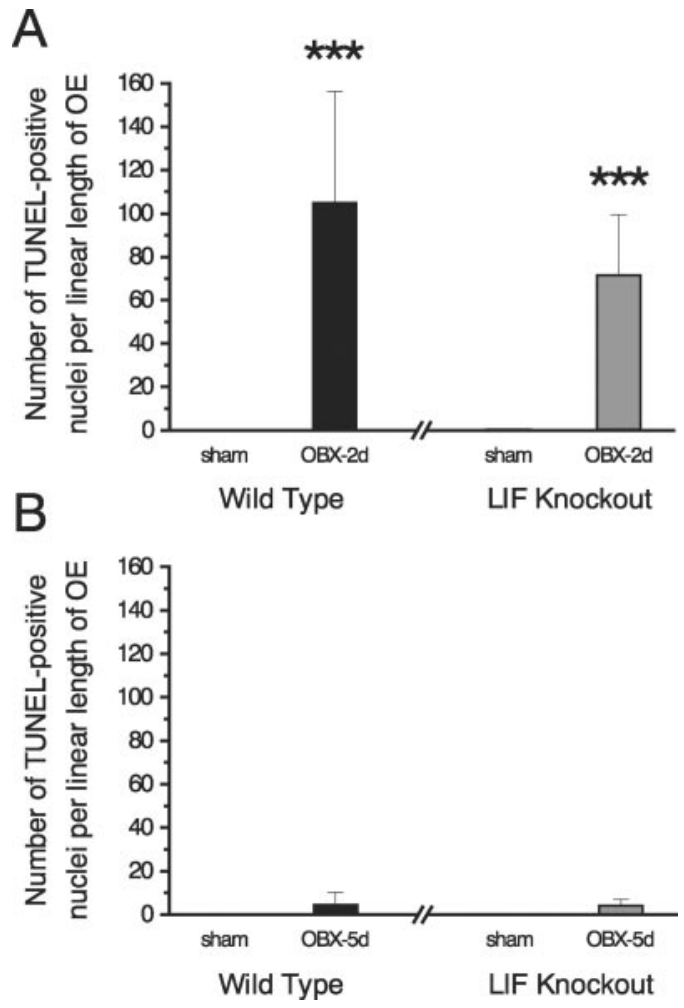

Figure 6. TUNEL labeling in the OE of LIF KO and WT littermates after unilateral OBX. Alternate sections from the same set used for BrdU labeling were used for TUNEL labeling. $A$, The number of TUNEL-positive nuclei per linear length of $\mathrm{OE}$ (arbitrary units) was analyzed at the peak of apoptosis, $2 \mathrm{~d}$ after OBX. As expected, there is a large increase in staining in the WT ( $>500$-fold over sham). The increase in TUNEL labeling in the LIF KO OE is also very significant, although somewhat less than in the WT (200-fold). The difference between the genotypes does not reach statistical significance, given the variation and the number of mice available for this experiment (3-5 animals per point). $B, A t 5 \mathrm{~d}$ after OBX, the number of TUNEL-labeled cells declines to nonsignificant values when compared with sham controls in both genotypes $(p>$ $0.05)$. Statistical analysis was performed with Student's $t$ test $\left.{ }^{* * *} p<0.001\right)$.

WT adult mice) (Schwartz-Levey et al., 1991), and killed animals $12 \mathrm{hr}$ later. Because this short survival time does not allow expression of specific cellular differentiation markers, the number of BrdU-positive cells in the OE was quantified with respect to their laminar position in the OE, i.e., basal or apical (Table 2). This was done to help distinguish between OSN progenitors (basal layer), immature/mature OSN (middle layer), and sustentacular cells (apical layer), although the disruption of the OE observed after LIF adenovirus infection hampers a simple analysis. After sham infection or infection with the LacZ virus, most of the BrdUpositive cells are found in the basal compartment of the OE (Fig. $7 G, H$, Table 2). This indicates that under these conditions, the adenoviral infection itself does not markedly perturb cell proliferation. In striking contrast, LIF overexpression yields many BrdU-positive cells in the apical OE (Fig. 7I), the quantitation of which revealed a 24 -fold increase of labeled cells (Table 2) $(p<$ $0.0001)$. Interestingly, the increase in BrdU labeling of the apical $\mathrm{OE}$ after LIF overexpression is accompanied by a corresponding decrease in BrdU labeling of the basal layer, yielding a total number of positive cells that is very similar in the LIF, LacZ, and sham OE (Table 2).

Given their laminar position in the OE after LIF overexpression (Fig. 7I,K), the BrdU-positive cells could belong to different cellular lineages. Indeed, the normal adult OE is known to contain proliferating sustentacular (Weiler and Farbman, 1998) and 


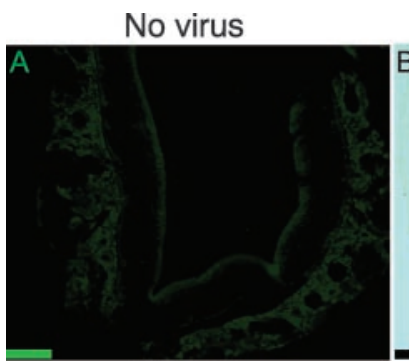

LIF stain
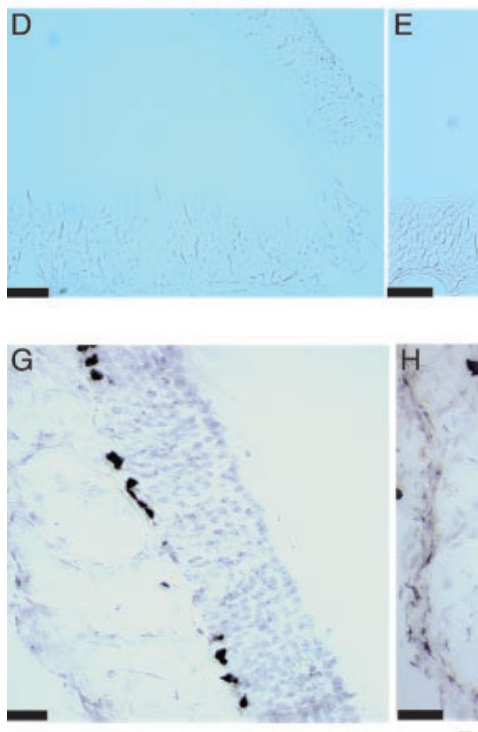

\section{TUNEL stain}
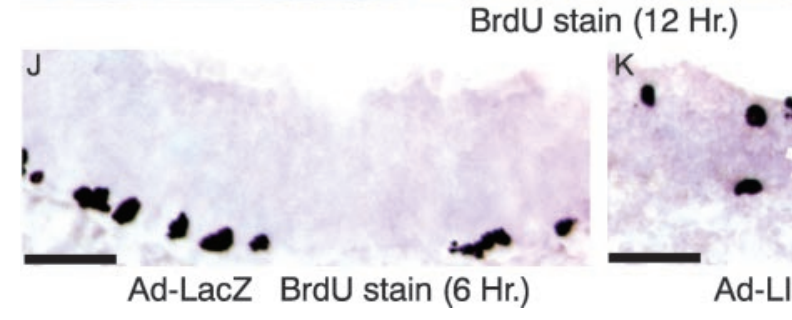

Ad-LIF

Figure 7. Delivery of LIF using an adenoviral vector induces major increases in TUNEL and BrdU labeling. Normal adult mice were intranasally infected with no virus $(A, D, G)$, with LacZ-expressing virus $(B, E, H, J)$, or with $L I F$-expressing virus $(C, F, I, K)$. The top row of pictures displays typical 0 E sections stained with the anti-LIF antibody $(A, C)$ or for $\beta$-galactosidase $(B)$. Both viruses infect and cause expression of the transgenes in the $0 \mathrm{E}$. The middle row of pictures illustrates results with TUNEL staining. There is a selective increase in TUNEL labeling caused by the LIF vector in all cell layers of the $0 E(F)$. Twelve hours after BrdU injection, the $\mathrm{LIF}$ vector also promotes the appearance of BrdU labeling specifically in the apical layer of the $0 \mathrm{E}$, whereas it decreases labeling in the basal cell layer $(I)$ (see also quantification of staining presented in Table 2). At an earlier time of BrdU labeling ( $6 \mathrm{hr}$ ), infection with the LIF virus yields labeled cells in all layers of the $\mathrm{OE}(K)$, and in some cases there appears to be a chain of labeled cells migrating from the basal to the apical layer ( $K$, white asterisk). Scale bar, $30 \mu \mathrm{m}$.

basal cells, both horizontal and globose (Monti-Graziadei and Graziadei, 1979; Schwartz-Levey et al., 1991). All of these cell types are thought to be of distinct cellular lineages, as revealed by in vivo retroviral lineage analysis in the normal adult $\mathrm{OE}$ (Caggiano et al., 1994; Hunter et al., 1994; Schwob, 2002). Therefore, our results $12 \mathrm{hr}$ after BrdU injection (Fig. 7I) suggest that exogenous LIF overexpression could induce the proliferation of sustentacular cells. However, when animals are killed at an earlier time point $(6 \mathrm{hr})$ after BrdU injection (Fig. $7 \mathrm{~K}$ ), our observation of what appear to be chains of BrdU-labeled cells extending from the basal to the apical OE suggest that cells of the neuronal lineage could also proliferate and be generated in the presence of exogenous LIF. On the other hand, given the fact that exogenous LIF overexpression in the normal OE appears to disrupt the OE, other cell types could be induced to proliferate in the OE, such as duct cells of Bowman's glands, which are known to actively proliferate in the $\mathrm{OE}$ after methyl-bromide injury (Schwob et al., 1994, 1995).

\section{Discussion}

The present study using both LIF KO mice and virally delivered exogenous LIF demonstrates for the first time the in vivo involvement of a specific endogenous cytokine in the olfactory neuron turnover in the adult mammal. We find that (1) LIF is necessary for OBX-induced proliferation of GBCs, (2) LIF is produced in part by injured OSNs, and (3) exogenous LIF stimulates cell turnover, increasing cell death and genesis in the presumptive OSN layer of the normal adult OE.

\section{Biological relevance of LIF in olfactory neuron turnover}

Among the factors previously reported to stimulate olfactory neuron production in vitro (LIF, EGF, TGF $\alpha$, TGF $\beta 1$ and $\beta 2$, BDNF, FGF2), we show that LIF is the only one to be reliably induced by OBX in vivo before mitosis rises in the GBC population. Supporting these and our previous results (Bauer et al., 2000), two recent reports showed that LIF mRNA and protein are expressed after OBX in the adult mouse OE (Nan et al., 2001; Getchell et al., 2002), although the peak of expression is later than in our studies. Differences in the time course of OBX-induced LIF expression may be explained by the age of mice used (6 weeks vs 3 months in our study). In addition, Nan et al. (2001) suggest that LIF immunoreactivity in the OE $2-3 \mathrm{~d}$ after OBX is associated with cellular processes of macrophages; however, in situ hybridization reveals that LIF mRNA is also detected in OSNs (Getchell et al., 2002). This apparent discrepancy between the cellular source of LIF in those two studies may be explained by the difficulty in detecting LIF at these low levels. In the present study, a highly sensitive in situ RT-PCR approach was required to localize the site of early LIF induction ( $8 \mathrm{hr}$ after OBX) to mature OSNs. This localization is supported by our antibody staining of LIF in axon bundles of the lamina propria, although this staining could be in axons of injured OSNs or in the ensheathing glia. A neuronal localization would be in agreement with previously reported expression of LIF in neuronal subpopulations of the adult rat brain (Lemke et al., 1996, 1997) and in peripheral ganglia (Cheng and Patterson, 1997). Thus, although macrophages can indeed be recruited in the OE after OBX (Nan et al., 2001; F. Jourdan, unpublished observations), it seems unlikely that these cells will be the source of LIF as early as $8 \mathrm{hr}$ after OBX. We do not rule out, however, the possibility that LIF could be synthesized by macrophages at a later 
Table 2. Effects of LIF overexpression in the nonlesioned OE of WT mice

\begin{tabular}{|c|c|c|c|c|c|}
\hline & $\begin{array}{l}\text { Cells expressing } \\
\text { the transgene }\end{array}$ & OE thickness $(\mu \mathrm{m})$ & TUNEL $^{+}$cells & $\begin{array}{l}\text { BrdU }^{+} \text {cells in } \\
\text { basal OE }\end{array}$ & $\begin{array}{l}\text { BrdU }^{+} \text {cells in } \\
\text { apical OE }\end{array}$ \\
\hline No virus & 0 & $64.37 \pm 3.52$ & $1.0 \pm 0.7$ & $54.0 \pm 1.7$ & $1.5 \pm 0.7$ \\
\hline Ad-LacZ & $96.0 \pm 2.3$ & $60.62 \pm 0.55$ & $1.8 \pm 0.7$ & $57.0 \pm 2.1$ & $1.5 \pm 0.7$ \\
\hline
\end{tabular}

Animals were unilaterally injected in the nostrils with saline (no virus), LacZ, or LIF adenovirus. Cell numbers were quantified in the entire 0 E of the injected side from 10 sections, and the average per section value is given. 0 E thickness was measured in the dorsal and the mediodorsal (septal) 0 E at reproducible anatomical levels. Statistical analysis between treatment groups was performed with Student's $t$ test $\left({ }^{*} p<0.05\right.$ and ${ }^{* * *} p<0.001$ when comparing LIF adenovirus-infected animals with both other groups).

time after OBX or by other cell types in the OE and the lamina propria, as suggested by our in situ RT-PCR experiments (Fig. 4).

Our finding that LIFR mRNA is upregulated after OBX, in parallel to LIF itself, is reminiscent of induction of interleukin signaling in the immune system. It is also consistent with the localization of LIFR and gp130 immunoreactivity to GBCs in the $\mathrm{OE}$ and to presumptive ensheathing glial cells in the lamina propria of adult mice after OBX (Nan et al., 2001). Thus, LIF action on these cells is very likely to be increased after injury.

Indeed, the biological relevance of LIF upregulation after OBX is revealed by our findings in LIF KO mice, in which the OBXinduced cell proliferation is completely absent at the normal peak time of neurogenesis. These data indicate that LIF is necessary for the lesion-induced proliferation of GBCs, without showing whether LIF triggers the entry into, or the acceleration of, the progenitor cell cycle. However, previous studies support the former interpretation; OBX-induced proliferation in the adult mouse OE involves an increased number of ${ }^{3} \mathrm{H}$-thymidineincorporating GBCs, i.e., an increased number of progenitors committed to enter into the cell cycle (Schwartz-Levey et al., 1991). Conversely, the absence of mitogen results in a simple blockade of the cell cycle, the length of which is constant in a given cell type (Sherr, 1996). In this regard, it would be of interest to study proliferation in the LIF KO at longer times after OBX.

A role for LIF in stimulating cells to enter the cell cycle is supported by our results with LIF overexpression in the normal adult OE. Here LIF enhances cell turnover, increasing both cell death and cell replacement in the presumptive OSN layer. It should be noted that the rates of cell death and proliferation in the uninjured, normal adult are apparently unchanged in LIF KO mice (Figs. 5, 6). Nonetheless, a tendency for reduced cell turnover in the OE of the LIF KO mouse, i.e., reduced proliferation and cell death, is already apparent $2 \mathrm{~d}$ after OBX (Figs. 5B, 6A).

Thus, our findings suggest that both exogenous and endogenous LIF in vivo can stimulate the OSN production that was reported previously in vitro (Satoh and Yoshida, 1997a,b). Another paracrine mediator(s) may be involved in related phenomena such as maintaining the steady-state rate of neurogenesis, neuronal differentiation, and axon outgrowth.

\section{Mode of action of LIF in the OE}

The immunocytochemical localization of LIFR complexes to GBCs and presumptive ensheathing glial cells (Nan et al., 2001) suggests that LIF can act on these cell types after OBX, both of which could be involved in the neurogenic response. LIF could directly trigger entry into the cell cycle, most likely via cyclin D1 induction (Lavoie et al., 1996; Sherr, 2000). This general mitogenic mechanism was characterized in OBX-induced stimulation of GBC proliferation in adult mouse OE (Kastner et al., 2000; Getchell et al., 2002), and it is triggered, among various transduction pathways, by JAK/STAT3 (Janus kinase/signal transducer and activator of transcription 3), which is known to mediate LIF action (for review, see Turnley and Bartlett, 2000) and is activated in the olfactory mucosa after OBX (Getchell et al., 2002). Alternatively, LIF could stimulate GBC proliferation indirectly via another paracrine messenger. For instance, LIF-producing cells grafted in the spinal cord selectively induce neurotrophin-3 in vivo (Blesch et al., 1999). However, the $2-3$ d delay between the peak of LIF mRNA/protein expression $(8 \mathrm{hr})$ and the onset of mitotic stimulation after OBX (3 d) (Schwartz-Levey et al., 1991) is in keeping with previously reported delays for the direct mitogen-triggered recruitment of adult neural stem cells, both in vitro (Ciccolini and Svendsen, 1998) and in vivo (Craig et al., 1996; for review, see Scheffler et al., 1999). Also, LIF stimulation of OE progenitor cell proliferation would be reminiscent of the recently demonstrated LIF mitogenic action in the developing cerebral cortex (Hatta et al., 2002). That LIF induction is found transient $(<24 \mathrm{hr})$, whereas OBX-induced increase of GBC proliferation in OE is sustained for several weeks (Schwartz-Levey et al., 1991), suggests that LIF would be involved specifically in the acute phase of $\mathrm{OE}$ reaction to lesion and that the new steady-state level of progenitor proliferation would be maintained by other signals.

It has been suggested recently that mature OSNs produce bone morphogenetic protein(s) (BMP) in vivo as a tonic inhibitor of progenitor proliferation (Shou et al., 1999, 2000). Olfactory neurogenesis could then be regulated by independent factors depending on the physiological context. This leads to an attractive model for in vivo combinatorial control of olfactory neurogenesis, in which OSNs control their own self-renewal. Indeed, BMP produced by mature OSNs might be primarily involved in the inhibition of GBC proliferation in basal conditions. Under conditions of increased neuronal loss, OSNs then synthesize LIF, which could act in synergy with BMP disappearance to stimulate GBC production of new neurons. Interestingly, LIF and BMPs can co-regulate and counter-regulate the expression of the same target genes in sympathetic neurons (Fann and Patterson, 1994a,b) via control of STAT3 phosphorylation (J.-G. Cheng and P. H. Patterson, unpublished observations).

In vitro studies have led to the concept that the OSN lineage is composed of colony-forming unit cells, hypothesized to be the OSN stem cells, and of two consecutive types of neuronal progenitors, i.e., transit amplifying cells that generate immediate neuronal precursors, which finally produce new neurons (for review, see Calof et al., 1998; Schwob, 2002). Although our results with the LIF KO OE demonstrate that LIF is required for injuryinduced neurogenesis, and the LIFR localization points to GBCs as a likely target for LIF action, the steps for how LIF stimulates new neuron production are not yet clear. Our results with LIF overexpression in the uninjured OE suggest that LIF may stimulate the production of putative neuronal progeny, without, however, enhancing the number of proliferating basal cells. This could be explained by the observation that LIF also stimulates cell death in this experiment, which makes any conclusions provisional.

Interestingly, however, a subpopulation of GBCs has been 
identified as being true olfactory stem cells, i.e., giving rise to different OE cell types, including neurons, horizontal basal cells, and sustentacular cells. This occurs after the OE has been completely destroyed by methyl-bromide exposure (Huard et al., 1998). Only in that case is the multilineage potential of some GBCs revealed (for review, see Schwob, 2002). Thus, in the exogenous LIF experiments, the question is whether LIF could stimulate the multilineage potential of some GBCs.

\section{New insights into LIF biology}

We here further document LIF upregulation after injury in the CNS (Minami et al., 1991; Banner et al., 1997; Jankowsky and Patterson, 1999) and PNS (Banner and Patterson, 1994; Curtis et al., 1994; Sun et al., 1994; Carlson et al., 1996; Kurek et al., 1996; Sun and Zigmond, 1996). The cytokine LIF thus appears as a key messenger in injury-induced reactions of the adult nervous system in vivo, where it has been found to regulate neuronal survival and phenotype, astrocyte activation, and inflammatory cell infiltration (Rao et al., 1993; Corness et al., 1996; Sendtner et al., 1996; Sun and Zigmond, 1996; Sugiura et al., 2000). In the previously characterized cases, however, LIF is induced in glial cells (Banner and Patterson, 1994; Curtis et al., 1994; Banner et al., 1997; Jankowsky and Patterson, 1999). In the OE in contrast, which is devoid of classical glia (Crews and Hunter, 1994), LIF appears to be produced in part by the lesioned neurons themselves and is involved in OSN turnover. Interestingly, LIF expression is also detected in presumptive sustentacular cells, which have been assigned a glial-like function in the $\mathrm{OE}$, and in presumptive ensheathing glial cells in the lamina propria (Fig. 4). It is known that OBX induces new gene expression in the ensheathing cells, albeit at later times after lesion than LIF induction (Michel et al., 1997b).

Interestingly, LIFR signaling has been shown recently to be involved in the control of neurogenesis in the adult subventricular zone (SVZ) stem cell system. Using adult heterozygous LIFR KO mice, Shimazaki et al. (2001) demonstrated a 55\% reduction in SVZ cell proliferation in vivo, accompanied by a $33 \%$ reduction in the number of tyrosine hydroxylase-expressing cells in the OB. It is worth noting that this effect was not seen during development, even in homozygous mutants, or during the early postnatal period. This leads to the hypothesis, supported by the present study, that LIF is broadly involved in the regulation of neurogenesis, specifically in the adult, where no increase in BrdU labeling is seen after injury in the LIF KO OE. The effect of LIFR signaling in the adult SVZ, however, is reported to be primarily for the maintenance of the self-renewing potency of neural stem cells (Shimazaki et al., 2001), whereas LIF overexpression in vivo in the normal adult $\mathrm{OE}$ may stimulate the production of neuronal progeny. We also have evidence that exogenous LIF virally delivered to the lateral ventricle can stimulate not only BrdU incorporation in the SVZ but also the number of BrdU-positive cells (presumptive neuronal progenitors) that migrate into the $\mathrm{OB}$ (Kerr et al., 2002). Interestingly, as is potentially the case for the OE, it is possible that there is an interplay between LIF (Shimazaki et al., 2001) and BMP (Lim et al., 2000) signaling in the SVZ. Such a relationship has also been characterized recently in embryonic stem (ES) cells plated at low density, where LIF, through an autocrine FGF-2 signaling pathway, induces the formation of committed neural stem cells from undifferentiated, multipotent ES cells, a process that is inhibited by endogenous BMP signaling (Tropepe et al., 2001).

\section{In vivo demonstration of mitogenic signaling by apoptotic cells}

The present study provides an example of a phenomenon that could prove to be of general importance: cells emitting a selfrenewing mitogenic signal while entering apoptosis. Such a mechanism has obvious value for tissue homeostasis. The special cell dynamics in the adult OE allowed us to observe this for OSN renewal, but the phenomenon need not be confined to this tissue. Concerning adult brain repair, there are reports of neuronal replacement after induction of neuronal apoptosis (Magavi et al., 2000; for review, see Kuhn et al., 2001; Magavi and Macklis 2001). Thus, understanding the molecular signals that lead to neuronal replacement after injury is a key step in developing therapeutic approaches for brain repair. Our study on the adult mammalian OE, which is well known for its capacity for neuronal replacement after injury, raises new clues about these mechanisms in the brain. If mitogen emission by early apoptotic cells turns out to be a widespread phenomenon, its occurrence in cancer could hamper therapies relying on induction of cell apoptosis.

\section{References}

Banner LR, Patterson PH (1994) Major changes in the expression of the mRNAs for cholinergic differentiation factor/leukemia inhibitory factor and its receptor after injury to adult peripheral nerves and ganglia. Proc Natl Acad Sci USA 91:7109-7113.

Banner LR, Moayeri NN, Patterson PH (1997) Leukemia inhibitory factor is expressed in astrocytes following cortical brain injury. Exp Neurol 147:1-9.

Bauer S, Mauduit C, Jourdan F, Benahmed M, Moyse E (2000) In vivo involvement of the cytokine LIF during lesion-induced renewal of olfactory sensory neurons in adult mouse. In: Neuro-immune interactions in neurologic and psychiatric disorders (Patterson PH, Kordon C, Christen Y, eds), pp 153-160. Fondation IPSEN. Berlin: Springer.

Blesch A, Uy HS, Grill RJ, Cheng JG, Patterson PH, Tuszynski MH (1999) Leukemia inhibitory factor augments neurotrophin expression and corticospinal axon growth after adult CNS injury. J Neurosci 19:3556-3566.

Buckland ME, Cunningham AM (1999) Alterations in expression of the neurotrophic factors glial cell line-derived neurotrophic factor, ciliary neurotrophic factor and brain-derived neurotrophic factor, in the targetdeprived olfactory neuroepithelium. Neuroscience 90:333-347.

Bugga L, Gadient RA, Kwan K, Stewart CL, Patterson PH (1998) Analysis of neuronal and glial phenotypes in brains of mice deficient in leukemia inhibitory factor. J Neurobiol 36:509-524.

Caggiano M, Kauer JS, Hunter DD (1994) Globose basal cells are neuronal progenitors in the olfactory epithelium: a lineage analysis using replication-incompetent retrovirus. Neuron 13:339-352.

Calof AL, Mumm JS, Rim PC, Shou J (1998) The neuronal stem cell of the olfactory epithelium. J Neurobiol 36:190-205.

Carlson CD, Bai Y, Ding M, Jonakait GM, Hart RP (1996) Interleukin-1 involvement in the induction of leukemia inhibitory factor mRNA expression following axotomy of sympathetic ganglia. J Neuroimmunol 70:181-190.

Cheng J-G, Patterson PH (1997) LIF is an autocrine factor for sympathetic neurons. Mol Cell Neurosci 9:372-380.

Ciccolini F, Svendsen CN (1998) Fibroblast growth factor 2 (FGF2) promotes acquisition of epidermal growth factor (EGF) responsiveness in mouse striatal precursor cells: identification of neural precursors responding to both EGF and FGF-2. J Neurosci 18:7869-7880.

Corness J, Shi T-J, Xu Z-Q, Brulet P, Hokfelt T (1996) Influence of leukemia inhibitory factor on galanin/GMAP and neuropeptide $\mathrm{Y}$ expression in mouse primary sensory neurons after axotomy. Exp Brain Res 112:79-88.

Craig CG, Tropepe V, Morshead CM, Reynolds BA, Weiss S, Van Der Kooy D (1996) In vivo growth factor expansion of endogenous subependymal neural precursor cell populations in the adult mouse brain. J Neurosci 16:2649-2658.

Crews L, Hunter D (1994) Neurogenesis in the olfactory epithelium. Perspect Dev Neurobiol 2:151-161.

Curtis R, Scherer SS, Somogyi R, Adryan KM, Ip NY, Zhu Y, Lindsay RM, DiStefano PS (1994) Retrograde axonal transport of LIF is increased by peripheral nerve injury: correlation with increased LIF expression in distal nerve. Neuron 12:191-204. 
Deckner ML, Frisen J, Verge VM, Hokfelt T, Risling M (1993) Localization of neurotrophin receptors in olfactory epithelium and bulb. NeuroReport 5:301-304.

Deckner ML, Risling M, Frisen J (1997) Apoptotic death of olfactory sensory neurons in the adult rat. Exp Neurol 143:132-140.

DeHamer MK, Guevara JL, Hannon K, Olwin BB, Calof AL (1994) Genesis of olfactory receptor neurons in vitro: regulation of progenitor cell divisions by fibroblast growth factors. Neuron 13:1083-1097.

Ensoli F, Fiorelli V, Vannelli B, Barni T, De Cristofaro M, Ensoli B, Thiele CJ (1998) Basic fibroblast growth factor supports human olfactory neurogenesis by autocrine/paracrine mechanisms. Neuroscience 86:881-893.

Estus S, Zacks WJ, Freeman RS, Gruda M, Bravo R, Johnson EM Jr (1994) Altered gene expression in neurons during programmed cell death: identification of c-jun as necessary for neuronal apoptosis. J Cell Biol 127:1717-1727.

Ezeh PI, Farbman AI (1998) Differential activation of ErbB receptors in the rat olfactory mucosa by transforming growth factor-alpha and epidermal growth factor in vivo. J Neurobiol 37:199-210.

Fann M-J, Patterson PH (1994a) Depolarization differentially regulates the effects of bone morphogenetic protein (BMP)-2, BMP-6, and activin A on sympathetic neuronal phenotype. J Neurochem 63:2074-2079.

Fann M-J, Patterson PH (1994b) Neuropoietic cytokines and activin A differentially regulate the phenotype of cultured sympathetic neurons. Proc Natl Acad Sci USA 91:43-47.

Farbman AI, Buchholz JA (1996) Transforming growth factor- $\alpha$ and other growth factors stimulate cell division in olfactory epithelium in vitro. J Neurobiol 30:267-280.

Farbman AI, Buchholz JA, Suzuki Y, Coines A, Speert D (1999) A molecular basis of cell death in olfactory epithelium. J Comp Neurol 414:306-314.

Gavrieli Y, Sherman Y, Ben-Sasson SA (1992) Identification of programmed cell death in situ via specific labeling of nuclear DNA fragmentation. J Cell Biol 119:493-501.

Getchell TV, Shah DS, Partin JV, Subhedar NK, Getchell ML (2002) Leukemia inhibitory factor mRNA expression is upregulated in macrophages and olfactory receptor neurons after target ablation. J Neurosci Res 67:246-254.

Goldstein BJ, Wolozin BL, Schwob JE (1997) FGF2 suppresses neurogenesis of a cell line derived from rat olfactory epithelium. J Neurobiol 33:411-428.

Hatta T, Moriyama K, Nakashima K, Taga T, Otani H (2002) The role of gp130 in cerebral cortical development: in vivo functional analysis in a mouse exo utero system. J Neurosci 22:5516-5524.

Herzog C, Otto T (1999) Regeneration of olfactory receptor neurons following chemical lesion: time course and enhancement with growth factor administration. Brain Res 849:155-161.

Holcomb JD, Mumm JS, Calof AL (1995) Apoptosis in the neuronal lineage of the mouse olfactory epithelium: regulation in vivo and in vitro. Dev Biol 172:307-323.

Hsu P, Yu F, Feron F, Pickles JO, Sneesby K, Mackay-Sim A (2001) Basic fibroblast growth factor and fibroblast growth factor receptors in adult olfactory epithelium. Brain Res 896:188-197.

Huard JM, Schwob JE (1995) Cell cycle of globose basal cells in rat olfactory epithelium. Dev Dyn 203:17-26.

Huard JM, Youngentob SL, Goldstein BJ, Luskin MB, Schwob JE (1998) Adult olfactory epithelium contains multipotent progenitors that give rise to neurons and non-neural cells. J Comp Neurol 400:469-486.

Hunter DD, Caggiano M, Kauer JS (1994) Lineage analysis of the olfactory epithelium using a replication-incompetent retrovirus. Chem Senses 19:683-693.

Jankowsky JL, Patterson PH (1999) Differential regulation of cytokine expression following pilocarpine-induced seizure. Exp Neurol 159:333-346.

Kastner A, Moyse E, Bauer S, Jourdan F, Brun G (2000) Unusual regulation of cyclin-dependent kinases cdk 2 and cdk4 during in vivo mitotic stimulation of olfactory neuron progenitors in adult mouse. J Neurochem 74:2343-2349.

Kerr BJ, Han J, Patterson PH (2002) Adenoviral delivery of LIF induces significant proliferation in neurogenic areas of adult mouse brain. Soc Neurosci Abstr 28:23.6.

Krishna NSR, Little SS, Getchell TV (1996) Epidermal growth factor receptor mRNA and protein are expressed in progenitor cells of olfactory epithelium. J Comp Neurol 373:297-307.

Kuhn HG, Palmer TD, Fuchs E (2001) Adult neurogenesis: a compensatory mechanism for neuronal damage. Eur Arch Psychiatry Clin Neurosci 251:152-158.

Kurek JB, Austin L, Cheema SS, Bartlett PF, Murphy M (1996) Upregulation of leukaemia inhibitory factor and interleukin-6 in transected sciatic nerve and muscle following denervation. Neuromuscul Disord 6:105-114.

Laemmli UK (1970) Cleavage of structural proteins during the assembly of the head of bacteriophage T4. Nature 227:680-685.

Lavoie JN, Rivard N, L'Allemain G, Pouyssegur J (1996) A temporal and biochemical link between growth factor-activated MAP kinases, cyclin D1 induction and cell cycle entry. Prog Cell Cycle Res 2:49-58.

Lemke R, Gadient RA, Schliebs R, Bigl V, Patterson PH (1996) Neuronal expression of leukemia inhibitory factor (LIF) in the rat brain. Neurosci Lett 215:205-208.

Lemke R, Gadient RA, Patterson PH, Bigl V, Schliebs R (1997) Leukemia inhibitory factor (LIF) mRNA-expressing neuronal subpopulations in adult rat basal forebrain. Neurosci Lett 229:69-71.

Lim DA, Tramontin AD, Trevejo JM, Herrera DG, Garcia-Verdugo JM, Alvarez-Buylla A (2000) Noggin antagonizes BMP signaling to create a niche for adult neurogenesis. Neuron 28:713-726.

MacDonald KPA, Murrell WG, Bartlett PF, Bushell GR, Mackay-Sim A (1996) FGF2 promotes neuronal differentiation in explant cultures of adult and embryonic mouse olfactory epithelium. J Neurosci Res 44:27-39.

Mackay-Sim A, Chuah MI (2000) Neurotrophic factors in the primary olfactory pathway. Prog Neurobiol 62:527-559.

Magavi SS, Macklis JD (2001) Manipulation of neural precursors in situ: induction of neurogenesis in the neocortex of adult mice. Neuropsychopharmacology 25:816-835.

Magavi SS, Leavitt BR, Macklis JD (2000) Induction of neurogenesis in the neocortex of adult mice. Nature 405:951-955.

Mahalik TJ (1996) Apparent apoptotic cell death in the olfactory epithelium of adult rodents: death occurs at different developmental stages. J Comp Neurol 372:457-464

Mahanthappa NK, Schwarting GA (1993) Peptide growth control of olfactory neurogenesis and neuron survival in vitro: roles of EGF and TGF- $\beta$ s. Neuron 10:293-305.

Margolis FL (1982) Olfactory marker protein (OMP). Scand J Immunol 9:181-199.

Martin-Villalba A, Herr I, Jeremias I, Hahne M, Brandt R, Vogel J, Schenkel J, Herdegen T, Debatin KM (1999) CD95 ligand (Fas-L/APO-1L) and tumor necrosis factor-related apoptosis-inducing ligand mediate ischemiainduced apoptosis in neurons. J Neurosci 19:3809-3817.

Michel D, Moyse E, Brun G, Jourdan F (1994) Induction of apoptosis in mouse olfactory neuroepithelium by synaptic target ablation. NeuroReport 5:1329-1332.

Michel D, Chatelain G, Mauduit C, Benahmed M, Brun G (1997a) Recent evolutionary acquisition of alternative pre-mRNA splicing and $3^{\prime}$ processing regulations induced by intronic B2 SINE insertion. Nucleic Acids Res 25:3228-3234.

Michel D, Moyse E, Trembleau A, Brun G, Jourdan F (1997b) Clusterin/ Apo J expression is associated with neuronal apoptosis in the olfactory mucosa of the adult mouse. J Cell Sci 110:1635-1645.

Minami M, Kuraishi Y, Satoh M (1991) Effects of kainic acid on messenger RNA levels of IL-1 beta, IL-6, TNF alpha and LIF in the rat brain. Biochem Biophys Res Commun 176:593-598.

Monti-Graziadei AG, Graziadei PPC (1979) Studies on neuronal plasticity and regeneration in the olfactory system: morphologic and functional characteristics of the olfactory sensory neurons. In: Neural growth and differentiation (Meisami A, Brazier MAB, eds), pp 373-396. New York: Raven.

Mowla SJ, Pareek S, Farhadi HF, Petrecca K, Fawcett JP, Seidah NG, Morris SJ, Sossin WS, Murphy RA (1999) Differential sorting of nerve growth factor and brain-derived neurotrophic factor in hippocampal neurons. J Neurosci 19:2069-2080.

Nan B, Getchell ML, Partin JV, Getchell TV (2001) Leukemia inhibitory factor, interleukin-6, and their receptors are expressed transiently in the olfactory mucosa after target ablation. J Comp Neurol 435:60-77.

Newman MP, Feron F, Mackay-Sim A (2000) Growth factor regulation of neurogenesis in adult olfactory epithelium. Neuroscience 99:343-350.

Ohta Y, Ichimura K (1999) Immunohistochemical localization of epidermal growth factors in mouse olfactory epithelium. Am J Rhinol 13:225-228. 
Ozawa K, Seo M, Imamura T (1997) A quantitative method for evaluation of FGF family and FGF receptor family gene expression by RT-PCR. Brain Res Protoc 1:211-216.

Rao MS, Sun Y, Escary JL, Perreau J, Tresser S, Patterson PH, Zigmond RE, Brulet P, Landis SC (1993) Leukemia inhibitory factor mediates an injury response but not a target-directed developmental transmitter switch in sympathetic neurons. Neuron 11:1175-1185.

Recher S, Raccurt M, Lambert A, Lobie PE, Mertani HC, Morel G (2001) Prenatal and adult growth hormone gene expression in rat lymphoid organs. J Histochem Cytochem 49:347-354.

Roskams AJ, Bethel MA, Hurt KJ, Ronnett GV (1996) Sequential expression of Trks A, B, and C in the regenerating olfactory neuroepithelium. J Neurosci 16:1294-1307.

Salehi-Ashtiani K, Farbman AI (1996) Expression of neu and neu differentiation factor in the olfactory mucosa of rat. Int J Dev Neurosci 14:801-811

Satoh M, Yoshida T (1997a) Enhancement of neuronal progenitor cell divisions by fibroblast growth factor- 2 and leukemia inhibitory factor in organ culture of murine olfactory epithelium. IFO Res Commun 18:13-19.

Satoh M, Yoshida T (1997b) Promotion of neurogenesis in mouse olfactory neuronal progenitor cells by leukemia inhibitory factor in vitro. Neurosci Lett 225:165-168.

Scheffler B, Horn M, Blumcke I, Laywell ED, Coomes D, Kukekov VG, Steindler DA (1999) Marrow-mindedness: a perspective on neuropoiesis. Trends Neurosci 22:348-357.

Schwartz-Levey M, Chikaraishi DM, Kauer JS (1991) Characterization of potential precursor populations in the mouse olfactory epithelium using immunocytochemistry and autoradiography. J Neurosci 11:3556-3564.

Schwob JE (2002) Neural regeneration and the peripheral olfactory system. Anat Rec 269:33-49.

Schwob JE, Huard JM, Luskin MB, Youngentob SL (1994) Retroviral lineage studies of the rat olfactory epithelium. Chem Senses 19(6):671-682.

Schwob JE, Youngentob SL, Mezza RC (1995) Reconstitution of the rat olfactory epithelium after methyl bromide-induced lesion. J Comp Neurol 359:15-37.

Sendtner M, Gotz R, Holtmann B, Escary JL, Masu Y, Carroll P, Wolf E, Brem G, Brulet P, Thoenen H (1996) Cryptic physiological trophic support of motoneurons by LIF revealed by double gene targeting of CNTF and LIF. Curr Biol 6:686-694.

Sherr CJ (1996) Cancer cell cycles. Science 274:1672-1677.

Sherr CJ (2000) The Pezcoller lecture: cancer cell cycles revisited. Cancer Res 60:3689-3695.
Shimazaki T, Shingo T, Weiss S (2001) The ciliary neurotrophic factor/leukemia inhibitory factor/gp130 receptor complex operates in the maintenance of mammalian forebrain neural stem cells. J Neurosci 21:7642-7653.

Shou J, Rim PC, Calof AL (1999) BMPs inhibit neurogenesis by a mechanism involving degradation of a transcription factor. Nat Neurosci 2:339-345.

Shou J, Murray RC, Rim PC, Calof AL (2000) Opposing effects of bone morphogenetic proteins on neuron production and survival in the olfactory receptor neuron lineage. Development 127:5403-5413.

Sugiura S, Lahav R, Han J, Kou S-Y, Banner LR, de Pablo F, Patterson PH (2000) Leukaemia inhibitory factor is required for normal inflammatory responses to injury in the peripheral and central nervous systems in vivo and is chemotactic for macrophages in vitro. Eur J Neurosci 12:457-466.

Sun Y, Zigmond RE (1996) Leukaemia inhibitory factor induced in the sciatic nerve after axotomy is involved in the induction of galanin in sensory neurons. Eur J Neurosci 8:2213-2220.

Sun Y, Rao MS, Zigmond RE, Landis SC (1994) Regulation of vasoactive intestinal peptide expression in sympathetic neurons in culture and after axotomy: the role of cholinergic differentiation factor/leukemia inhibitory factor. J Neurobiol 25:415-430.

Suzuki Y, Farbman AI (2000) Tumor necrosis factor-alpha-induced apoptosis in olfactory epithelium in vitro: possible roles of caspase 1 (ICE) caspase 2 (ICH-1), and caspase 3 (CPP32). Exp Neurol 165:35-45.

Tropepe V, Hitoshi S, Sirard C, Mak TW, Rossant J, van der Kooy D (2001) Direct neural fate specification from embryonic stem cells: a primitive mammalian neural stem cell stage acquired through a default mechanism. Neuron 30:65-78.

Turnley AM, Bartlett PF (2000) Cytokines that signal through the leukemia inhibitory factor receptor-beta complex in the nervous system. J Neurochem 74:889-899.

Weiler E, Farbman AI (1998) Supporting cell proliferation in the olfactory epithelium decreases postnatally. Glia 22:315-328

Yasuno H, Fukazawa K, Fukuoka T, Kondo E, Sakagami M, Noguchi K (2000) Nerve growth factor applied onto the olfactory epithelium alleviates degenerative changes of the olfactory receptor neurons following axotomy. Brain Res 887:53-62.

Zhu M, Oishi K, Lee SC, Patterson PH (2001) Studies using LIF knockout mice and a LIF adenoviral vector demonstrate a key anti-inflammatory role for this cytokine in cutaneous inflammation. J Immunol 166:20492054. 